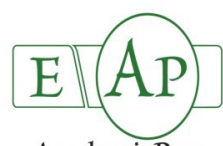

AcademicPres

\title{
$S$-Genotype Profiles of Turkish Apricot Germplasm
}

\section{Kadir Ugurtan YILMAZ¹, Busra BASBUG ${ }^{1}$, Kahraman GURCAN², Hasan PINAR ${ }^{1}$, Julia HALASZ ${ }^{3}$, Sezai ERCISLI ${ }^{4 *}$, Aydın UZUN ${ }^{1}$, Erdogan COCEN $^{5}$}

\author{
${ }^{I}$ Erciyes University, Faculty of Agriculture, Department of Horticulture, 38039 Kayseri, \\ Turkey;ugurtan@erciyes.edu.tr;busrabasbug_90@hotmailcom; hasanpinar@erciyes.edu.tr;aydinuzun@erciyes.edu.tr \\ 2ExiyesUniwersity, Faculty of Agriculture,Department of Agricultural Biotechnology,38039Kayseri,Turkey;; kgurcan@erciyesedu.tr \\ ${ }^{3}$ Corvinus University, Faculty of Horticultural Science, Department of Genetics and Plant Breeding, 44Ménesi Str, 1118 Budapest, Hungary;juliabalasz@uni-corvinus.bu \\ ${ }^{4}$ Ataturk University, Faculty of Agriculture, Department of Horticulture, 25240Erzurum, Turkey;sercisli@hotmailcom (*orresponding author) \\ ${ }^{5}$ Apricot Research Institute, Malatya, Turkey; elmas29@gmail.com
}

\begin{abstract}
In flowering plants, gametophytic self-incompatibility, controlled by a single locus with several allelic variants, is one of the major problems preventing self-fertilization. Among fruit trees, apricots show to a high degree self-incompatibility, especially in Middle-Asian and Iranian-Caucasian eco-geographical groups. In the present study, self-(in)compatibility characteristics of a total of 236 apricot genotypes (218 Turkish and 18 foreign) found within the National Apricot Germplasms of Apricot Research Institute in Malatya, Turkey was studied. Analyses were carried out by using four primer pairs (SRc-F and SRc-R, EM-PC2consFD and EM-PC3consRD, AprSC8-R and PaConsI-F, AprFBC8-F and AprFBC8-R). A total of 11 S-RNase alleles $\left(S_{2}, S_{3}, S_{6}, S_{7}, S_{8}, S_{9}, S_{11}, S_{12}, S_{13}, S_{20}\right.$ and $\left.S_{c}\right)$ were determined in the 236 apricot genotypes. As Turkish and foreign apricot genotypes are determined mostly self-incompatible, the data obtained hereby might be of good use for apricot breeding programs and more practically, for apricot new plantations; thus pollinator cultivars should be considered when selfincompatible apricot cultivars are being used.
\end{abstract}

Keywords: alleles, Prunus armeniaca, primers, self-(in)compatibility

\section{Introduction}

The world apricot production is 3.95 million $t /$ year and Mediterranean countries provide a great majority of this production. Turkey is the most important country in terms of apricot production in the world, with nearly 800.000 t per year (FAO, 2012). In Turkey $28.489 \mathrm{t}$ of table fruit and $90.321 \mathrm{t}$ of dried apricots have been exported (FAO, 2011). Although Turkey is not the homeland of apricot, the specie has been adapted very well to Anatolia conditions and is successfully grown on this land for centuries. Previously, apricot production in Turkey was based on seedlings obtained from seeds; however, in the last 50-60 years this figure changed and grafting with true to name cultivars on seedlings has been more common. Grafting technique increased the quality and quantity of apricot production in Turkey and enhances the importance of apricots both in domestic and foreign markets (Yilmaz et al., 2013).

In Rosaceae, many fruit species such as Japanese pear (Pyrus pyrifolia), apple (Malus $\times$ domestica), sweet cherry (Prunus avium), almond (Prunus dulcis) and apricot (Prunus armeniaca) exhibit selfincompatibility (SI) and require pollination with pollen from compatible SI genotypes for stable fruit production. Aside from this practical importance, SI of Rosaceae is interesting from an evolutionary point of view, because the common ancestor of Asterid and Rosid is thought to exhibit S-RNase-based gametophytic selfincompatibility (Igic and Kohn, 2001).

In new apricot plantations, self-incompatibility is one of the important problems and now days, in order to solve this issue, molecular techniques are being used to determine self-(in) compatibility in apricot cultivars (Burgos et al., 1998; Halasz et al., 2005, 2007; Yilmaz, 2008; Yilmaz et al., 2013). Genetically, SI of Rosaceae is controlled by a single $S$ locus with multiple alleles (Sonneveld et al., 2003). The $S$-gene product is a ribonuclease enzyme, while the pollen product is an F-box protein (Entani $e t a l$., 2003; Romero et al.,2004).

The conventional methods to determine self-(in)compatibility are time consuming and can be effected by environmental factors (Zhang et al., 2003). Even more, molecular markers have been developed in recent years to determine the self-incompatibility of genotypes (Yaegaki et al., 2001). The Sc-haplotype was long suspected to be a pollen-part mutant of the $S_{8}$-haplotype (Halasz et al., 2007) with a 353-bp insertion in the $S F B_{C}$ gene (Vilanova et al., 2005). Although most apricot cultivars are self-compatible, selfincompatibility is present in some interesting cultivars (Hormaza et al., 2007). Up to 2010, a total of 20 SI (self-incompatible) alleles and one SC (self-compatible) allele were determined among European 
68

eco-geographical group of apricot (Burgos et al., 1998; Halasz et al., $2005,2007,2010)$ and studies undertaken to determine new SI alleles in apricot have been continuing(Halasz et al., 2013).

The aim of this study was to identify $S$-allele constitution of several apricot genotypes from apricot germplasm in MalatyaTurkey using polymerase chain reaction (PCR) with specific primer pairs.

\section{Materials and Methods}

\section{Materials}

A total of 236 apricot genotypes were used in this study from the Apricot Research Institute in Malatya, Turkey. From all genotypes studied, 18 were foreign, originated from different countries, while the rest of the 218 genotypes had Turkish origin (Table 1).

\section{DNA Isolation}

Genomic DNA was extracted from full-expanded young apricot leaf samples, using the Cetyltrimethyl Ammonium Bromide (CTAB) method (Doyle and Doyle, 1987).

\section{PCR studies with S-RNase and SFB-specificprimers}

For first intron region, SRc-R (Vilanova et al., 2005) and SRc-F (Romero et al., 2004) primer pair were used to determine Sc allele, which yielded bands at 353 bp at apricot cultivars (Vilanova et al., 2005). PCR products were separated on an ABI 3500 capillary electrophoresis instrument (Applied Biosystems, Foster City, CA, USA) at the core laboratory of the Genome and Stem Cell Centre (GENKOK) in Erciyes University, Kayseri, Turkey. For the identification of the SC-haplotype, a 2step approach was used. An allele-specific reverse primer, AprSC8R (Halasz et al., 2010), was designed to selectively amplify the $\mathrm{Sc} / \mathrm{S}_{8}-\mathrm{RNase}$ allele and used in combination with PaConsI F (Sonneveld et al., 2003). AprFBC8-F (5'- CAT GGA AAA AGC TGA CTT ATG G -3') and AprFBC8-R (5'- GCC TCT AAT GTC ATC TAC TCT TAG -3') were used for detecting $S F B_{\mathrm{C} / 8}$ allele (Halász et al, 2007). The amplification was carried out using a temperature profile according to Halász et al. (2010).

For the second intron, PCR was conducted according to Sutherland et al. (2004) using the degenerate primers EMPC2 consFD and EM-PC3consRD. For PCR amplification in a 20-mL reaction volume, containing $1 \mathrm{X}$ PCR buffer (Thermo) with the final concentrations of $10 \mathrm{mM}$ Tris- $\mathrm{HCl}(\mathrm{pH} 8.3), 50$ $\mathrm{mM} \mathrm{KCl}, 2.0 \mathrm{mM} \mathrm{MgCl}, 0.2 \mathrm{mM}$ of dNTPs, $0.3 \mathrm{mM}$ of each primer, and $1.0 \mathrm{U}$ of Taq DNA polymerase (Thermo). The PCR products were electrophoresed in $1.5 \%(\mathrm{w} / \mathrm{v})$ agarose gel, stained with ethidium bromide $(0.5 \mathrm{lg} / \mathrm{mL})$ using $1 \times \mathrm{TAE}$ buffer, at $110 \mathrm{~V}$ for $2 \mathrm{~h}$ and visualized under UV light. Molecular size of the amplified fragments was estimated using a 100-bp ladder (Thermo). PCR's were repeated three times to determine the clear band size from apricot DNA.

\section{Evaluation of data}

To determine the exact size of the S-RNase first intron region fragments under $100 \mathrm{bp}$ DNA ladder (Invitrogen), the fluorescently labelled products were run on an automated sequencer ABI Prism 3500 Genetic Analyzer. For the determination of size (genotyping), GENEMAPER software and the GS600 LIZ size standard (Applied Biosystems) were used.

The second intron PCR products were separated by electrophoresis in 1.2\% TAE agarose gels for $2 \mathrm{~h}$ at $100 \mathrm{~V}$, whereas DNA bands were visualised by ethidium bromide staining. Fragment lengths were estimated by comparison with the 1-kb DNA ladder (Promega, Madison, WI, USA). In the case of unknown alleles, PCR products were cloned and sequenced in an automated sequencer and analysed as described by Halász et al. (2010).

\section{Results and Discussion}

The determination of the $S$-genotypes of 236 Turkish and foreign apricot genotypes was carried out using the SRc-F and SRcR consensus primers (Vilanova et al., 2005) for the first intron and EM-PC2consFD / EM-PC3consRD primers (Sutherland et al., 2004 ) for the second intron analysis of the $S$-RNase gene (Table 1). AprFBC8 $\mathrm{F}$ and $\mathrm{R}$ primers were used for discrimination of $S F B_{\mathrm{C} / 8}$ allele (Halász et al., 2007). The size of the PCR products was compared with those previously published by other researchers (Vilanova et al., 2005; Halász et al., 2007, 2010). For $S_{8}$ and $S_{c}$ alleles, although Vilanova et al. (2005) and Halasz et al. (2010) reported as 353 and also, Halasz et al. (2013) reported as 355 bp, the hereby result obtained was $354 \mathrm{bp}$ band size. These differences might be explained by the genetic analyzers that affect the sensitivity of the method (Cachi and Wünsch, 2014).

A total $11 S$-RNase alleles $\left(S_{2}, S_{3}, S_{6}, S_{7}, S_{8}, S_{9}, S_{11}, S_{12}, S_{13}, S_{20}\right.$ and $S_{C}$ ) were determined in the 236 apricots genotypes, while a total of $8\left(S_{2}, S_{6} S_{7}, S_{8}, S_{9}, S_{11}, S_{13}\right.$ and $\left.S_{C}\right)$ were determined within the foreign apricot genotypes, which were used as control (Table 1). Halasz et al. (2010) conducted a study to determine the $S$ genotypes of a set of Turkish and Hungarian apricot cultivars by amplification of their $S$-RNase intron regions. A specific primer (AprSC8) for $S_{C}$ and $S_{8}$ was designed to anneal within the second intron region of the $S_{C^{-}}$and $S_{8}$-RNase alleles. This primer pair amplified a fragment in the case of $S_{8} / S_{C \text {-alleles. They reported that }}$

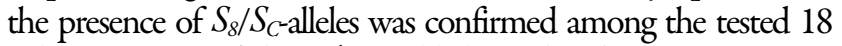
cultivars. Some of them ('Canakkale', 'Ethembey', 'Kayisi Erigi', 'Mektep', 'Sam' and 'Yerli Izmir') were proved as self-compatible $(S c S c)$. Two Turkish cultivars shared the $S_{C} S_{8}$-genotype ('Ethembey' and 'Mektep'). Also, it was reported in their study that AprSC8 primer could distinguish between the $S I$ and $S C$ cultivars. Twelve previously described $S$-alleles were identified among the Turkish cultivars. $S_{9}$ was the most frequent $S$-allele in the tested Turkish germplasm (occurring in 72 cultivars), followed by $S_{8}(51)$, $S_{6}(43), S_{2}, S_{13}$ (34 each), $S_{19}(17), S_{7}(43), S_{C}(52), S_{3}(25), S_{I I}(18)$, $S_{12}(25)$, while $S_{20}$ allele was only found in seven cultivars. Also, $S_{C} S_{8}$ allel combination was found in 16 genotypes.

In the present study, 'Artvin PA' $\left(S_{2} S_{7}\right)$, 'Hasanbey' $\left(S_{2} S_{9}\right)$, 'Cataloglu' $\left(S_{6} S_{9}\right)$, 'Ozal' $\left(S_{6} S_{9}\right)$, 'Soganci' $\left(S_{6} S_{9}\right)$, 'Gec Aprikoz' $\left(S_{6} S_{11}\right)$, 'Ziraat Okulu' $\left(S_{6} S_{12}\right)$, 'X1 Zerdali' $\left(S_{6} S_{12}\right)$, 'Ordubat' $\left(S_{7} S_{12}\right)$, 'X2 Zerdali' $\left(S_{7} S_{12}\right)$, 'Agerik' $\left(S_{7} S_{13}\right)$, 'Mektep' $\left(S_{\$} S_{C}\right)$, 'Yegen' $\left(S_{8} S_{11}\right)$, 'Adilcevaz-5' $\left(S_{9} S_{13}\right)$, 'Hacihaliloglu' $\left(S_{9} S_{13}\right)$, 'Kabaası' $\left(S_{9} S_{13}\right)$, 'Kamelya' $\left(S_{9} S_{13}\right)$, 'No.2 Zerdali' $\left(S_{9} S_{13}\right)$, 'X3 Zerdali' $\left(S_{9} S_{20}\right)$, 'Aprikoz' $\left(S_{11} S_{13}\right)$, 'Kayıs Erigi' $\left(S_{11} S_{\text {plum }}\right.$ ?), 'Alyanak' $\left(S_{2} S_{8}\right)$, 'Sam' $\left(S_{2} S_{C}\right)$, 'Dortyol-4' $\left(S_{2} S_{19}\right)$, 'Sebbiyki' $\left(S_{2} S_{19}\right)$, 'Hacklı' $\left(S_{6} S_{8}\right)$, 'Sakıt-1' $\left(S_{7} S_{8}\right)$, 'Turfanda Izmir' $\left(S_{\gamma_{8}}\right)$, 'Yerli Izmir' $\left(S_{7} S_{C}\right)$, 'Akcadag Gunay' $\left(S_{9} S_{3}\right)$, 'Ismailaga' $\left(S_{9} S_{11}\right)$, 'Kadioglu' $\left(S_{9} S_{8}\right)$, 'Seftalioglu' $\left(S_{9} S_{8}\right)$, 'Alioglu-49' $\left(S_{12} S_{8}\right)$, 'Adilcevaz-3' $\left(S_{13} S_{19}\right)$, 'Guz 
Table 1. S-genotype profiles of Turkish Apricot Germplasm in Malatya Apricot Research Institute, Turkey

\begin{tabular}{|c|c|c|c|c|c|}
\hline 1 intron & 2 intron & Sc/S S $_{8}$-Rnase & $\mathrm{SFBc} / 8$ & S-genotype & Genotypes \\
\hline 354,354 & 2800,2800 & + & Sc & $\mathrm{ScSc}$ & 2,5, 1343, 1860, 12-Kadıoğlu,M 1343,M 1345,M 1346, Mehmet Yüksel 1860, Y9, Ambrossia \\
\hline 332,354 & 900,2800 & + & $\mathrm{Sc}$ & $\mathrm{S}_{2} \mathrm{Sc}$ & 7,17,23 A,01-K-13, Canino, Karacabey, Paviot, Rakowsky, SeferÇoban,Şam, Tokaloğu Yalova, \\
\hline 332,332 & 900,900 & - & - & $\mathrm{S}_{2} \mathrm{~S}_{2}$ & $65 \mathrm{~K}, 31-\mathrm{K}-04, \mathrm{~K} 5002$, Roxana \\
\hline 332,424 & 900,1300 & - & - & $\mathrm{S}_{2} \mathrm{~S}_{6}$ & K0618 \\
\hline 332,402 & 900,820 & - & - & $\mathrm{S}_{2} \mathrm{~S}_{7}$ & 11,2216, 11/1-2P,Artvin PA, Y1 \\
\hline 332,354 & 900,2800 & + & $\mathrm{S}_{8}$ & $\mathrm{~S}_{2} \mathrm{~S}_{8}$ & $62 \mathrm{~K}, 693 \mathrm{~K}, \mathrm{~K} 0616, \mathrm{~K} 0621$,Alyanak,Ziraat Okulu \\
\hline 332,204 & 900,500 & - & - & $\mathrm{S}_{2} \mathrm{~S}_{9}$ & DeRona, Hasanbey,M2254, \\
\hline 332,304 & 900,1700 & - & - & $\mathrm{S}_{2} \mathrm{~S}_{11}$ & $\mathrm{~K} 0617, \mathrm{~K} 3811$ \\
\hline 332,378 & 900,1250 & - & - & $\mathrm{S}_{2} \mathrm{~S}_{13}$ & $2639, \mathrm{Y} 3$ \\
\hline 332,424 & 900,1980 & - & - & $\mathrm{S}_{2} \mathrm{~S}_{19}$ & Dörtyol-4,Şebbiyki,Y11 \\
\hline 332,222 & 900,500 & - & - & $\mathrm{S}_{2} \mathrm{~S}_{20}$ & K0613 \\
\hline 332,236 & 900,1270 & - & - & $\mathrm{S}_{2} \mathrm{~S}_{\mathrm{x}}$ & 1295 \\
\hline 268,424 & 310,2800 & + & Sc & $\mathrm{S}_{3} \mathrm{Sc}$ & 5103 \\
\hline 268,268 & 310,310 & - & - & $\mathrm{S}_{3} \mathrm{~S}_{3}$ & M 1299, M 1302,M 1342,M 2251 \\
\hline 268,424 & 310,1300 & - & - & $\mathrm{S}_{3} \mathrm{~S}_{6}$ & Şekerpare,Şekerpare Iğdır \\
\hline 268,402 & 310,820 & - & - & $\mathrm{S}_{3} \mathrm{~S}_{7}$ & M 1364 \\
\hline 268,268 & 310,2800 & + & $S_{8}$ & $\mathrm{~S}_{3} \mathrm{~S}_{8}$ & Kayseri PA,K3812 \\
\hline 268,204 & 310,500 & - & - & $\mathrm{S}_{3} \mathrm{~S}_{9}$ & AkçadağGünay \\
\hline 268,262 & 310,370 & - & - & $\mathrm{S}_{3} \mathrm{~S}_{12}$ & Adilcevaz-2,K3816 \\
\hline 268,378 & 310,1250 & - & - & $\mathrm{S}_{3} \mathrm{~S}_{13}$ & Erken Ağerik \\
\hline 268,268 & 310,1250 & - & - & $\mathrm{S}_{3} \mathrm{~S}_{13}$ & M2234 \\
\hline ----, ---- & 310,1980 & - & - & $\mathrm{S}_{3} \mathrm{~S}_{19}$ & 5101 \\
\hline $268,-\cdots$ & 310,1980 & - & - & $\mathrm{S}_{3} \mathrm{~S}_{19}$ & 1342 \\
\hline 268,424 & 310,1980 & - & - & $\mathrm{S}_{3} \mathrm{~S}_{19}$ & 3803, Saktt-3, Tokaloğlu İzmir \\
\hline 268,222 & 310,500 & - & - & $\mathrm{S}_{3} \mathrm{~S}_{20}$ & KöfteKayısı \\
\hline 268,402 & $310,-$ & - & - & $\mathrm{S}_{3} \mathrm{~S}_{3}$ & M2243,1364 \\
\hline 268,424 & $310,-$ & - & - & $\mathrm{S}_{3} \mathrm{~S}_{2}$ & CasnaDrenova, İmrahor \\
\hline 424,354 & 1300,2800 & + & $\mathrm{Sc}$ & $\mathrm{SSSc}_{6}$ & $614,07-\mathrm{K}-01,07-\mathrm{K}-09,07-\mathrm{K}-14,07-\mathrm{K}-15$ \\
\hline 424,424 & 1300,1300 & - & - & $\mathrm{S}_{6} \mathrm{~S}_{6}$ & Adilcevaz-4,Dörtyol-1, Güz Eriği,M2250,Sakıt-4 \\
\hline 424,354 & 1300,820 & - & - & $\mathrm{S}_{6} \mathrm{~S}_{7}$ & K5106 \\
\hline 424,402 & 1300,820 & - & - & $\mathrm{S}_{6} \mathrm{~S}_{7}$ & 01-K-12,K 4207 \\
\hline 424,354 & 1300,2800 & + & $\mathrm{S}_{8}$ & $\mathrm{~S}_{6} \mathrm{~S}_{8}$ & 4201,Hackkz \\
\hline 424,204 & 1300,500 & - & - & $\mathrm{S}_{6} \mathrm{~S}_{9}$ & Çataloğlu, Dörtyol-2,K 4206, K 5105, M 2245, No.1 Zerdali, Özal, Precoce de Boulbon, Soğanc \\
\hline 424,304 & 1300,1700 & - & - & $\mathrm{S}_{6} \mathrm{~S}_{11}$ & 13, GeçAprikoz, K3860, Güz Aprikozu \\
\hline 424,262 & 1300,370 & - & - & $\mathrm{S}_{\mathrm{G}} \mathrm{S}_{12}$ & 23,GÜ-103,M2236,No.1 Zerdali(ZiraatOkulu),X1Zerdali \\
\hline 424,378 & 1300,1250 & - & - & $\mathrm{S}_{6} \mathrm{~S}_{13}$ & Mahmudun Erĭğ, Silistre de Rona, XXZerdali \\
\hline,-- & 1300,1250 & - & - & $\mathrm{S}_{6} \mathrm{~S}_{13}$ & K 3814 \\
\hline 424,424 & 1300,1980 & - & - & $\mathrm{S}_{6} \mathrm{~S}_{19}$ & Sakt-1 \\
\hline $424,-$ & 1300,1980 & - & - & $\mathrm{S}_{6} \mathrm{~S}_{19}$ & Saktt-2, Ordubat Benzeri \\
\hline $424,-$ & $1300,-$ & - & - & $\mathrm{S}_{6} \mathrm{~S}_{:}$ & Levent \\
\hline 402,354 & 820,2800 & + & $\mathrm{Sc}$ & S-Sc & 6,1344,66K, M 1344, Yerli İzmir \\
\hline 402,424 & 820,2800 & + & $\mathrm{Sc}$ & S-Sc & 10 \\
\hline 402,424 & 820,2800 & + & S & $S_{7} S_{?}$ & Cafona \\
\hline 402,402 & 820,820 & - & - & $\mathrm{S}_{7} \mathrm{~S}_{7}$ & 3, 1292, 1294, 1296, M 1294, Proyma, Tokaloğlu Konya Ereğli \\
\hline 402,354 & 820,2800 & + & $\mathrm{S}_{8}$ & $\mathrm{~S}_{7} \mathrm{~S}_{8}$ & AbuzerGülen, TurfandaEskiMalatya, Turfanda İzmir \\
\hline,- 354 & 820,2800 & + & $\mathrm{Sc}$ & S-Sc & Kurmizi \\
\hline 402,204 & 820,500 & - & - & S.S & Kurukabuk \\
\hline 402,304 & 820,1700 & - & - & $\mathrm{S}_{7} \mathrm{~S}_{11}$ & M2241 \\
\hline 402,262 & 820,370 & - & - & $\mathrm{S}_{7} \mathrm{~S}_{12}$ & 615 , Ordubat, X2Zerdali \\
\hline 402,378 & 820,1250 & - & - & $\mathrm{S}_{7} \mathrm{~S}_{13}$ & Ağerik,M2252,Saktt-7 \\
\hline 402,402 & 820,1980 & - & - & $\mathrm{S}_{7} \mathrm{~S}_{19}$ & M 1296 \\
\hline 402,424 & 820,1980 & - & - & $\mathrm{S}_{7} \mathrm{~S}_{19}$ & SivasPA \\
\hline 402,236 & 820,1270 & - & - & $\mathrm{S}_{-} \mathrm{S}_{\mathrm{x}}$ & GÜ-2,M2620, TokaloğluErzincan \\
\hline 304,236 & 820,1270 & - & - & $S_{7} S_{x}$ & K0614 \\
\hline 332,354 & $820,--$ & - & - & $S_{7} S_{:}$ & 1293 \\
\hline $354,-$ & $820,--$ & - & - & $S_{7} S_{:}$ & 1346 \\
\hline 354,354 & 2800,2800 & + & $\mathrm{S}_{8} / \mathrm{Sc}$ & $\mathrm{S}_{8} \mathrm{Sc}$ & $\begin{array}{l}\text { Precoce de Colomer, 18, 2239, 3808, 4202, Çanakkale, K 4205, M 1277, M 1298, M 2437, Mektep, Precoce de Tyrinthe, } \\
\text { Tokaloğu 1295, Y5, Y8, Y10 }\end{array}$ \\
\hline 354,354 & 2800,2800 & + & $\mathrm{S}_{8}$ & $\mathrm{~S}_{8} \mathrm{~S}_{8}$ & 20,2249, Royal, Erivan \\
\hline 354,204 & 2800,500 & + & $S_{8}$ & $\mathrm{~S}_{8} \mathrm{~S}_{9}$ & Çöloğlu, Kadıoğlu,Şeftalioğlu, GÜ-13, GÜ-50,M2256, No.8Zerdali,Perfection, Y7 \\
\hline 354,304 & 2800,1700 & + & $\mathrm{S}_{8}$ & $\mathrm{~S}_{8} \mathrm{~S}_{11}$ & 2213, Yeğen \\
\hline 354,304 &,- 1700 & + & $\mathrm{S}_{8}$ & $\mathrm{~S}_{8} \mathrm{~S}_{11}$ & $31-\mathrm{K}-05$ \\
\hline 354,378 & 2800,1250 & + & $\mathrm{S}_{8}$ & $\mathrm{~S}_{8} \mathrm{~S}_{13}$ & M2246,69K \\
\hline,-- & 2800,1980 & + & $\mathrm{S}_{8}$ & $\mathrm{~S}_{8} \mathrm{~S}_{19}$ & $61 \mathrm{~K}$ \\
\hline 354,222 & 2800,500 & + & $S_{8}$ & $\mathrm{~S}_{8} \mathrm{~S}_{20}$ & $92-58-01,92-58-02$ \\
\hline 204,204 & 500,500 & - & - & S, $S_{9}$ & 12,31-Hachaliloğlu, GÜ-52,M 2257,M 2235 \\
\hline 204,304 & 500,1700 & - & - & $S_{9} S_{11}$ & İsmailağa \\
\hline 204,262 & 500,370 & - & - & $S_{9} S_{12}$ & $8,691,92-23-01, M 2242$ \\
\hline 204,354 & 500,370 & - & - & $S_{9} S_{12}$ & Alkaya \\
\hline,-- & 500,370 & - & - & $S_{9} S_{12}$ & K5104 \\
\hline 204,378 & 500,1250 & - & - & $S_{9} S_{13}$ & Adilcevaz-5,Hachaliloğlu, Kabaaşı, Kamelya, Mahmut Ölmez,No.2Zerdali \\
\hline 204,424 & 500,1250 & - & - & $S_{9} S_{13}$ & 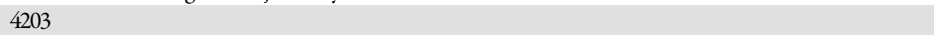 \\
\hline 204,222 & 500,500 & - & - & $\mathrm{S}_{9} \mathrm{~S}_{20}$ & X3Zerdali \\
\hline 204,236 & 500,1270 & - & - & $\mathrm{S}_{9} \mathrm{~S}_{\mathrm{x}}$ & $92-58-03$ \\
\hline 304,354 & 1700,2800 & + & $\mathrm{Sc}$ & $S_{11} S_{c}$ & Polenais \\
\hline 304,262 & 1700,370 & - & - & $\mathrm{S}_{\mathrm{II}} \mathrm{S}_{12}$ & $68 \mathrm{~K}, \mathrm{~K} 0620$ \\
\hline 304,378 & 1700,1250 & - & - & $S_{11} S_{13}$ & Aprikoz,EB,K3809 \\
\hline
\end{tabular}




\begin{tabular}{|c|c|c|c|c|c|}
\hline 1 intron & 2 intron & Sc/S S $_{8}$ Rnase & SFBc/8 & $S$-genotype & Genotypes \\
\hline 304,354 & 1700,1700 & - & - & $\mathrm{S}_{11} \mathrm{~S}_{\mathrm{plum}}$ & Kayısı Eriği \\
\hline 362,354 & 370,2800 & + & $S_{8}$ & $\mathrm{~S}_{12} \mathrm{~S}_{8}$ & 49-Alioğu \\
\hline 262,262 & 370,370 & - & - & $S_{12} S_{12}$ & 92-23-02, K 5001, Tevfik Yildırm \\
\hline 262,378 & 370,1250 & - & - & $\mathrm{S}_{12} \mathrm{~S}_{13}$ & 31-K-03,GÜ-8,K 4204,M2244 \\
\hline 354,354 & $370,-$ & - & - & $\mathrm{S}_{12} \mathrm{~S}$ & K3813 \\
\hline 378,354 & 1250,2800 & + & Sc & $\mathrm{S}_{13} \mathrm{Sc}$ & $269,63 \mathrm{~K}, 64 \mathrm{~K}, 67 \mathrm{~K}$ \\
\hline 378,378 & 1250,1250 & - & - & $\mathrm{S}_{13} \mathrm{~S}_{13}$ & $692 \mathrm{~K}, \mathrm{M} 2435$ \\
\hline 378,424 & 1250,1980 & - & - & $S_{13} S_{19}$ & Adilcevaz-3 \\
\hline 354,354 & 1980,1980 & - & - & $\mathrm{S}_{19} \mathrm{~S}_{19}$ & M2240 \\
\hline 454,222 & 1980,500 & - & - & $S_{19} S_{20}$ & Tekeler \\
\hline 222,222 & 500,500 & - & - & $S_{21} S_{20}$ & Hirmanlı \\
\hline
\end{tabular}

Aprikozu' $\left(S_{6} S_{11}\right)$, 'Kayseri PA' $\left(S_{3} S_{8}\right)$, 'Saktt-3' $\left(S_{3} S_{19}\right)$, 'Tokaloglu Izmir' $\left(S_{3} S_{19}\right)$, 'Imrahor' $\left(S_{3} S_{3}\right)$, 'Sekerpare' $\left(S_{3} S_{6}\right)$ had the same alleles with those of Halasz et al. (2010).

Never the less, there were some differences at three apricot cultivars from the results of Halasz et al. (2010) such as 'Karacabey' $\left(\mathrm{S}_{2} \mathrm{Sc}_{\mathrm{c}} / \mathrm{S}_{2} \mathrm{~S}_{8}\right)$, 'Ziraat Okulu' $\left(\mathrm{S}_{2} \mathrm{~S}_{8} / \mathrm{S}_{2} \mathrm{Sc}\right)$ and 'Canakkale' $\left(\mathrm{S}_{8} \mathrm{Sc}_{\mathrm{c}} /\right.$ $\mathrm{ScSc})$. Also, the second allele at 'Levent' $\left(\mathrm{S}_{6} \mathrm{~S}_{\text {? }} / \mathrm{S}_{6} \mathrm{~S}_{19}\right)$ was not obtained in the current experiment. Otherwise, although Halasz et al. (2010) could not determine second allele for 'Dortyol-2' $\left(\mathrm{S}_{6} \mathrm{~S}_{9} /\right.$ $\left.S: S_{9}\right)$, 'Mahmudun Erigi' $\left(\mathrm{S}_{6} \mathrm{~S}_{13} / \mathrm{S}_{5} \mathrm{~S}_{13}\right)$ and 'Cologlu' $\left(\mathrm{S}_{9} \mathrm{~S}_{8} / \mathrm{S}_{9} \mathrm{~S}_{5}\right)$, the hereby study determined second alleles for the mentioned genotypes (Table 1). These differences should come because of gel images or PCR conditions.

Mehlenbacher $e t$ al. (1991) reported that the European group of apricot (Europe, North America, South Africa and Australia are included) may be described as self-compatible. It was reported by Halasz et al. (2013) to support the $S$-genotype determinations, as first intron lengths were also determined for all genotypes using fluorescently labelled primers and automated sizing on a capillary sequencer. Analysis of the first intron in 63 wild-grown apricot accessions from Turkey showed that 17 of 63 apricot accessions had $355 \mathrm{bp}$ fragment. This fragment size was previously attributed to both the $S_{C^{-}}$and $S_{8}-R N$ ase alleles (Halasz et al., 2007).

Vilanova et al. (2005) used SRc-R and SRc-F primer pair for 10 apricot cultivars to determine their $S$ alleles. Six of 10 apricot genotypes were obtained via reciprocal crossing. They determined apricot genotypes that had $S c$ allele, which yielded at $353 \mathrm{bp}$. It was reported with previous studies that most of the European cultivars had $S c$ allele, whereas old Turkish cultivars were self-incompatible (Yilmaz, 2008; Halasz et al., 2010).

Since coding regions of the $S_{\S}$ and $S_{C}$-RNase alleles are identical, discrimination between the 2 alleles was not possible. In apricot, self-compatibility is attributed to a pollen-part mutation: a 353 bp insertion in the SFB gene. To distinguish between the selfincompatible (SI) and self-compatible (SC) accessions, a previously designed specific primer pair (AprFBC8) can be used (Halasz et al., 2010), which amplifies a fragment of approximately $500 \mathrm{bp}$ in the case of $S F B_{\mathrm{C}}$-allele, while genotypes carrying the $S F B_{8}$-allele show a fragment of approximately $150 \mathrm{bp}$ (Halasz et al., 2013). Thus, Halasz et al. (2013) determined 17 apricot accessions carrying $S F B_{8}$-allele among 63 apricots from Turkey using AprFBC8 primer pair and they were stated as self-incompatible.

Based on the structure of $S$-RNase, many pairs of primers have been developed for Prunus species, such as Pru-C2 and PCE-R (Tao et al., 1999a; Yamane et al, 2001), SRc-F and EMPC5consRD, SRc-F and PM-C5 (Vilanova et al., 2005; Sutherland et al., 2004; Habu et al., 2008), ASIII and AmyC5R (Tamura et al., 2000), EM-PC2consFD and ED-PC3cons-RD
(Sutherland et al., 2004), PaConsI-F and PaConsI-R, PaConsII-F and PaConsII-R (Sonneveld et al., 2003). Yaegaki et al. (2001) first determined $S$-RNase genotypes using the primer pair Pru-C2 and Pru-C5. Tao et al. (2002) cloned novel $S_{8}$-RNase and $S c$-RNase using Pru-C2 and PCE-R Recently, the $S$-genotypes of 14 Japanese apricot cultivars native to Japan were determined using Pru-C2 and PCE-R, SRc-F and EM-PC5consRD, SRc-F and PM-C5 (Habu et al., 2008). The primer pair Pru-C2 and PCE-R was developed from C2 and C3 in Prunus by Tao et al. (1999) and Yamane $e t a l$. (2001) and is considered as the universal primer pair for determining the $S$-genotypes in Japanese apricot (Habu et al.,2008).

Halasz et al. (2013) carried out a study to determine $S$ genotypes of wild-growing Turkish apricots by PCR amplification of the S-RNase intron regions and SFB gene, in order to characterize their sexual (in) compatibility phenotype. The authors determined the complete $S$-genotype of 63 wild-grown apricot accessions that originated in the Erzincan region. Ten previously described and 2 new $S$-alleles (provisionally labeled $S_{\mathrm{X}}$ and $S_{\mathrm{Y}}$ ) were identified in the studied genotypes. $S_{2}$ was the most frequent $S$ allele in the tested germplasm (occurred in 19 accessions), followed by $S_{8}(17), S_{19}(16), S_{3}(13), S_{12}(11), S_{6}(10)$ and $S_{7}(10)$, while $S_{9-}$, $S_{11}$ and $S_{13}$-alleles were found in 8 accessions each. A total of 36 different $S$-genotypes were assigned to the tested accessions. The $S_{\mathrm{C}-\text { allele responsible for self-compatibility in apricot was not }}$ present, indicating that all accessions were self-incompatible. The analysis of $S$-allele frequencies allowed to conclude the close relationship of wild-grown and cultivated apricots in Turkey and helped to raise hypotheses that may explain the high occurrences of $S_{2}$-and $S_{8}$-alleles.

One of the most important factors in apricot crop evolution was the emergence of self-compatibility, which has resulted in a serious loss of genetic diversity in Europe and the Mediterranean Basin (Pedryc et al., 2009; Bourguiba et al., 2012). In a previous study, Halasz et al. (2010) detected an uneven distribution of the $S_{C}$-allele in Turkish apricot cultivars: no self-compatible cultivar was found among 11 tested genotypes in the Eastern Region, while 7 out of 14 tested cultivars from the Western part of the country were self-compatible. Although the 55 cultivars analyzed in their study did not reveal a sound conclusion regarding the place of the origin of self-compatibility in apricot, the increasing number of $S_{C}$ cultivars from East to West was suggestive.

\section{Conclusion}

Turkey is a main producer of apricot. Also, there are broad genetic variation apricot cultivated areas. Determination of $S$ allele constitution of apricot germplasm is very important for 
orchard management and breeding programs. Within the current study it was determined $S$-allele constitution of apricot gemplasm in Turkey and the results showed that there were big variations among apricot genetic material studied with regard to $S$ allele constitution.

\section{Acknowledgments}

This work was supported by the Erciyes University Scientific Research Projects Unit (Project No: FYL-20155818) and authors thanks to Erciyes University for the financial support.

\section{References}

Bourguiba H, Audergon JM, Krichen L, Trifi-Farah N, Mamouni A, Trabelsi S, D’Onofrio C, Asma BM, Santoni S, Khadari B (2012). Loss of genetic diversity as a signature of apricot domestication and diffusion into the Mediterranean Basin. BMC Plant Biology 12(1):1.

Burgos L, Pérez-Tornero O, Ballester J, Olmos E (1998). Detection and inheritance of stylar ribonucleases associated with incompatibility alleles in apricot. Sexual Plant Reproduction 11:153-158.

Cachi AM, Wünsch A (2014). S-genotyping of sweet cherry varieties from Spain and $S$-locus diversity in Europe. Euphytica 197(2):229-236.

Doyle JJ, Doyle JL (1987). A rapid DNA isolation procedure for small quantities of fresh leaf tissue. Phytochemical Bulletin 19:11-15.

Entani T, Iwano M, Shiba H, Che SF, Isogai A, Takayama S (2003). Comparative analysis of the self-incompatibility (S-) locus region of Prunus mume: identification of a pollen-expressed F-box gene with allelic-diversity. Genes Cells 8:203-213.

FAO (2011).FAOStatistics Database. urww.fao.org.

FAO (2012).FAOStatistics Database. wrww.fao.org.

Habu T, Matsumoto D, Fukuta K, Esumi T, Tao R, Yaegaki H, Yamaguchi M, Matsuda M, Konishi T, Kitajima A, Yamada T (2008). Cloning and characterization of twelve S-RNase alleles in Japanese apricot (Prunus mume Sieb. et Zucc.). Journal Japanese Society Horticultural Science 77:374-381.

Halasz J, Hegedus A, Herman R, Stefanovits-Banyai E, Pedryc A (2005). New self-incompatibility alleles in apricot (Prunus armeniaca L.) revealed by stylar ribonuclease assay and S-PCR analysis. Euphytica 145:57-66.

Halász J, Pedryc A, Hegedűs A (2007). Origin and dissemination of the pollen-part mutated SC-haplotype which confers self-compatibility in apricot (Prunus armeniaca L.). New Phytologist 176:792-803.

Halasz J, Pedryc A, Ercisli S, Yilmaz KU, Hegedus A (2010). S-genotyping support the genetic relationships between Turkish and Hungarian Apricot Germplasm. Journal of the American Society for Horticultural Science 135:410-417.

Halasz J, Hegedus A, Szikriszt B, Ercisli S, Orhan E, Unlu HM (2013). The $S$-genotyping of wild-grown apricots reveals only self-incompatible accessions in the Erzincan region of Turkey. Turkish Journal of Biology 1:733-740.

Hormaza JI, Yamane H, Rodrigo J (2007). Apricot genome mapping and molecular breeding in plants. In: Kole C (Ed). Fruits and Nuts, Vol 4. Springer-VerlagBerlin Heidelberg.
Igic B, Kohn JR (2001). Evolutionary relationships among selfincompatibility RNases. Proceedings of the National Academy Sciences ofUSA 98:13167-13171.

Mehlenbacher SA, Cociu V, Hough LF (1991). Apricots (Prunus). In: MooreJN, Ballington JR(Eds). Genetic resources of temperate fruit and nut crops, Chapter 2. ISHS, Wageningen, Netherlands pp 63-108.

Pedryc A, Ruthner S, Herman R, Krska B, Hegedus A, Halasz J (2009). Genetic diversity of apricot revealed by a set ofSSR markers from linkage group G1.Scientia Horticulturae 121:19-26.

Romero C, Vilanova S, Burgos L, Martinez-Calvo J, Vicente M, Llacer G, Badanes ML (2004). Analysis of the S-locus structure in Prunus armeniaca L. identification of S-haplotype $S$-RNase and F-box genes. Plant Molecular Biology 56:145-157.

Sonneveld T, Tobutt KR, Robbins TP (2003). Allele-specific PCR detection of sweet cherry self-incompatibility $(S)$ alleles $S_{1}$ to $S_{16}$ using consensus and allele-specific primers. Theoretical and Applied Genetics 107:1059-1070.

Sutherland BG, Robbins TP, Tobutt KR (2004). Primers amplifyinga range of Prunus $S$-alleles. Plant Breeding 123:582-584.

Tamura M, Ushijima K, Sassa H, Hirano H, Tao R, Gradziel TM, Dandekar AM (2000). Identification of self-incompatibility genotypes of almond by allele-specific PCR analysis. Theoretical and Applied Genetics 101:344349.

Tao R, Yamane H, Sugiura A, Murayama H, Sassa H, Mori H (1999). Molecular typing ofS-alleles through identification, characterization and cDNA cloning for S-RNases in sweet cherry. Journal of the American Society for Horticultural Science 124:224-233.

Tao R, Habu T, Namba A, Yamane H, Fuyuhiro F, Iwamoto K, Sugiura A (2002). Inheritance of Sf-RNase in Japanese apricot (Prunus mume) and its relation to self-compatibility. Theoretical and Applied Genetics 105:222-228.

Vilanova S, Romero C, Llacer G, Badanes ML (2005). Identification of self(in) compatibility alleles in apricot by PCR and sequence analysis. Journal of the American Society for Horticultural Science 130:893-898.

Yaegaki H, Shimada T, Moriguchi T, Hayama H, Haji T, Yamaguchi M (2001). Molecular characterization of S-RNase genes and S-genotypes in the Japanese apricot (Prunus mume Sieb. et Zucc.). Sexual Plant Reproduction 13:251-257.

Yamane H, Tao R, Sugiura A, Hauck NR, Iezzoni AF (2001). Identification and characterization of $S$-RNases in tetraploid sour cherry (Prunus cerasus). Journal of the American Society for Horticultural Science 126:661-667.

Yilmaz KU (2008). Phenological, morphological and pomological characteristics of some local apricot genotypes and determination of their genetic relationships and self-incompatibility by molecular markers. Department of Horticulture Institute of Basic and Applied Sciences, University ofCukurova, $\mathrm{PhD}$ Thesis (in Turkish).

Yilmaz KU, Kafkas S, Paydaş-Karg S (2013). Determination of Self(in)compatibility in Turkish Apricot Genotypes. Fruit Science (Meyve Bilimi) 1:34-40 (in Turkish).

ZhangSL, Cao SM, Wu HQ(2003). Self-incompatibility genotypes of fruit trees and their identification methods. Journal of Fruit Science 20:358363. 